\title{
Influence of Different Irrigation Regimes and Systems of Cultivation on Physiological Growth Parameters of Rice Cultivars
}

\author{
G.V. Venkataravana Nayaka ${ }^{*}$, G. Prabhakara Reddy ${ }^{2}$, R. Mahendra Kumar ${ }^{3}$, \\ P. Sudhakar ${ }^{4}$ and G. Surekha ${ }^{5}$
}

${ }^{1}$ Department of Agronomy, S. V. Agricultural College, Tirupati, ANGRAU. A.P. India

${ }^{2}$ Department of Agronomy, S.V. Agricultural College, Tirupati, India

${ }^{3}$ Department of Agronomy, ICAR-Indian Institute of Rice Research, Hyderabad, India

${ }^{4}$ Department of Crop Physiology, S.V. Agricultural College, Tirupati, India

${ }^{5}$ Department of Soil Science, ICAR-Indian Institute of Rice Research, Hyderabad, India

*Corresponding author

\section{A B S T R A C T}

\begin{tabular}{|l|}
\hline K e y w o r d s \\
Rice, Cultivars, \\
Leaf area index, \\
Crop growth rate \\
and relative growth \\
rate, Irrigation \\
regimes and \\
Systems of \\
cultivation \\
\hline Article Info \\
\hline $\begin{array}{l}\text { Accepted: } \\
\text { 10 June } 2019 \\
\text { Available Online: } \\
\text { 10 July } 2019\end{array}$ \\
\hline \hline
\end{tabular}

A field experiment was conducted on clay loam soils of Indian Institute of Rice Research (IIRR) formerly Directorate of Rice Research (DRR), Rajendranagar, Hyderabad, Telangana during the kharif seasons of 2017 and 2018, to study the "productivity and water use efficiency of rice cultivars under different irrigation regimes and systems of cultivation" The treatments consisted of two irrigation regimes viz., Alternate wetting and drying and Saturation as main plot treatments, three establishment methods viz., System of Rice Intensification (SRI), Drum Seeding (DS) and Normal transplanting (NTP) as sub plot treatments and four cultivars namely DRR Dhan 42, DRR Dhan 43, MTU-1010 and NLR-34449 as sub-sub plot treatments summing up to 24 treatment combinations laid out in splitsplit plot design with three replications. Among the cultivars, DRR Dhan 43 recorded significantly highest LAI and CGR at all the crop growth stages in both the years of study and in pooled means as compared to other cultivars. The growth analysis, viz., LAI and CGR were significantly recorded higher in SRI than NTP during both the years of study. Alternative wetting and drying recorded significantly highest LAI and CGR than saturation in all the growth stages.

\section{Introduction}

Rice (Oryza sativa L.) is the foremost staple food for more than $50 \%$ of the world's population. It is estimated that by the year 2025, farmers in the world should produce about $60 \%$ more rice than at present to meet the food demands of the expected world population at that time (Thakur et al., 2011). It is widely grown in India due to its wider adaptability. Food security in India is closely linked to sustainable rice production as it 
contributes to more than 42 per cent of the total food grain production and is the staple food for more than two thirds of Indian population. However, adequate water availability for rice production is becoming a major problem owing to depleting groundwater levels, water quality degradation and rising demands from other sectors. Rainfall patterns in many areas are becoming more unreliable, with extremes of drought and floods occurring at unexpected time. Traditional planting has been the most important and common method of crop establishment practice under irrigated lowland rice ecosystems in tropical Asia.

In irrigated lowland rice which not only consumes more water but also causes wastage of water resulting in degradation of land. In recent years to tackle this problem, many methods of cultivation have been developed and one among them is System of Rice Intensification (SRI). LAI is the component of crop growth analysis that accounts for the ability of the crop to capture light energy and is critical to understand the function of many crop management practices. Leaf area index can have importance in many areas of agronomy and crop production through its influence: light interception, crop growth, weed control, crop-weed competition, crop water use and soil erosion (Sonnentag et al., 2007). Growth and yield characteristics of any cultivar depend on genetic and environmental factors. Among the different production factors, varietal selection at any location plays an important role. Proper crop management depends on the growth characteristics of various varieties to get maximum benefit from new genetic material. Among the different water-saving irrigation methods in rice, the most widely adopted is alternate wetting and drying (AWD). Many of the rice cultivars vary in their performance under different systems of cultivation. Therefore present experiment was conducted to study physiological parameters LAI, CGR and RGR of rice cultivars grown under different irrigation regimes and systems of cultivation for getting higher yield of rice.

\section{Materials and Methods}

The field experiment comprises of 24 treatment combinations conducted at Indian Institute of Rice Research (IIRR) formerly Directorate of Rice Research (DRR) farm, Rajendranagar, Hyderabad during the kharif seasons of 2017 and 2018. located at $17^{\circ} 19^{\prime} \mathrm{N}$ latitude, $78^{\circ} 23^{\prime}$ 'E longitude and an altitude of $542.3 \mathrm{~m}$ above mean sea level. It represents the Southern Telangana Agro-climatic Zone of Telangana state. According to Troll's climatic classification, it falls under semi-arid tropics (SAT). During the crop growth period, a total rainfall of $990.4 \mathrm{~mm}$ was received in 50 rainy days in the first year and $375.6 \mathrm{~mm}$ in 26 rainy days in the second year. The weekly mean maximum and minimum temperature on an average of $30.4{ }^{0} \mathrm{C}, 31.2^{0} \mathrm{C}$ and $19.9{ }^{0} \mathrm{C}$, $18.2^{0} \mathrm{C}$ were recorded during 2017 and 2018 respectively. The treatments consisted of two irrigation regimes viz., Alternate wetting and drying and Saturation as main plot treatments, three establishment methods viz., System of Rice Intensification (SRI) with spacing of 25 $\mathrm{cm} \times 25 \mathrm{~cm}$, Drum Seeding (DS) with spacing of $20 \mathrm{~cm} \times 10 \mathrm{~cm}$ and Normal transplanting (NTP) with spacing of $20 \mathrm{~cm} \mathrm{x} 15 \mathrm{~cm}$ as sub plot treatments and four Cultivars namely DRR Dhan 42, DRR Dhan 43, MTU-1010 and NLR-34449 as sub-sub plot treatments laid out in split-split plot design with three replications. The area of each gross plot was 7 x $3 \mathrm{~m}^{2}$. Seedlings were transplanted with an average of one seedling per hill in the SRI method of planting. FYM at @ $10 \mathrm{t} \mathrm{ha}^{-1}$ was uniformly applied to all the plots before final puddling and levelling. The recommended dose of phosphorus @ $60 \mathrm{~kg} \mathrm{P}_{2} \mathrm{O}_{5} \mathrm{~kg} \mathrm{ha}^{-1}$ as single super phosphate (SSP) was applied to all the treatments uniformly as basal and 
potassium @ $40 \mathrm{~kg} \mathrm{~K} \mathrm{~K}_{2} \mathrm{O} \mathrm{ha}^{-1}$ as muriate of potash (MOP) was applied in two splits, 75 per cent as basal and the remaining 25 per cent at $75 \mathrm{DAS} / \mathrm{DAT}$. Recommended dose of nitrogen $\left(120 \mathrm{~kg} \mathrm{ha}^{-1}\right)$ was applied through urea in three splits, 50 per cent as basal, 25 per cent at $50 \mathrm{DAS} / \mathrm{DAT}$ and the remaining 25 per cent at 75 DAS/DAT.

Observations viz., LAI, CGR and RGR, were recorded at 30, 60, 90 DAS/DAT and harvest. The LAI (Leaf area index), CGR (Crop growth rate) and RGR (Relative growth rate) were estimated with the following formula:

\section{Leaf area index}

Leaf area $\left(\mathrm{cm}^{2}\right)$ of three randomly selected hills from each plot was measured at 30, 60, 90 DAS/DAT and harvest by using LICOR 3100 automatic leaf area meter. The leaf area index (LAI) is the ratio of leaf area per plant to the ground area occupied by each plant (spacing).

LAI $=\frac{\text { Leaf area }\left(\mathrm{cm}^{2}\right)}{\text { Ground area }\left(\mathrm{cm}^{2}\right)}$

Crop growth rate $\left(\mathrm{g} \mathrm{m}^{-2} \mathrm{day}^{-1}\right)$

$\mathrm{CGR}=\frac{\mathrm{W}_{2}-\mathrm{W}_{1}}{\mathrm{t}_{2}-\mathrm{t}_{1}} \mathrm{P}$

Where, $\mathrm{W}_{1}$ and $\mathrm{W}_{2}$ are the values of dry weights of plant $(\mathrm{g})$ harvested from equal but separate areas of ground, $(P)$ at times $t_{1}$ and $t_{2}$ in days, respectively. CGR is expressed in $g$ $\mathrm{m}^{-2}$ day $^{-1}$.

Relative growth rate $\left(\mathrm{g} \mathrm{g}^{-1}\right.$ day $\left.^{-1}\right)$

$\mathrm{RGR}=\frac{\ln \mathrm{W}_{2}-\ln \mathrm{W}_{1}}{\mathrm{t}_{2}-\mathrm{t}_{1}}$
Where, $\mathrm{W}_{1}$ and $\mathrm{W}_{2}$ are the dry weights $(\mathrm{g})$ at times $t_{1}$ and $t_{2}$ in days, respectively.

In is natural logarithm. RGR is expressed in $\mathrm{g}$ $\mathrm{g}^{-1}$ day $^{-1}$

\section{Results and Discussion}

The average leaf area index (LAI) of rice increased at a slower rate up to 30 DAS/DAT and thereafter it increased steadily with the ontogeny of the plant reaching a peak value at 90 DAS/DAT, but there after it decreased gradually towards maturity due to senescence of leaves (Table 1 and Fig. 1). CGR and RGR increased slowly between 30-60 DAS/DAT, thereafter increased linearly between 60-90 DAS/DAT and finally it decreased sharply towards harvest (Table 2, 3 and Fig. 2, 3). The LAI, CGR and RGR of rice increase as crop growth advances and reaches a maximum at about heading or flowering (Yoshida, 1981).

\section{Effect of irrigation regimes}

Among the irrigation regimes, alternative wetting and drying recorded significantly higher LAI at 30, 60, 90 DAS/DAT and harvest during both the years of study as compared to saturation (Table 1 and Fig. 1).

The crop growth rate values were significantly influenced by irrigation regimes in all the growth stages during both the years of study and in pooled means. Alternative wetting and drying recorded significantly higher CGR from 30-60 DAS/DAT, 60-90 DAS/DAT and 90 DAS/DAT- harvest during both the years of study as compared to saturation (Table 2 and Fig. 2). While the both irrigation regimes recorded similar values of relative growth rate in all the growth stages during both the years of study and in pooled means (Table 3 and Fig. 3). These results are in conformity with Sandhu et al., (2012), Kumar et al., (2014) and Sudhakara (2015). 
Table.1 Leaf area index of rice cultivars as influenced by different irrigation regimes and establishment methods during Kharif 2017 and 2018

\begin{tabular}{|c|c|c|c|c|c|c|c|c|c|c|c|c|}
\hline \multirow[t]{3}{*}{ Treatments } & \multicolumn{12}{|c|}{ Leaf area index } \\
\hline & \multicolumn{3}{|c|}{30 DAS/DAT } & \multicolumn{3}{|c|}{60 DAS/DAT } & \multicolumn{3}{|c|}{90 DAS/DAT } & \multicolumn{3}{|c|}{ At harvest } \\
\hline & 2017 & 2018 & Pooled & 2017 & 2018 & Pooled & 2017 & 2018 & Pooled & 2017 & 2018 & Pooled \\
\hline \multicolumn{13}{|c|}{ Irrigation regimes (I) } \\
\hline$I_{1}: A W D$ & 0.60 & 0.64 & 0.62 & 3.47 & 3.56 & 3.53 & 5.03 & 5.41 & 5.22 & 4.46 & 4.79 & 4.62 \\
\hline $\mathbf{I}_{2}:$ Saturation & 0.55 & 0.57 & 0.56 & 3.06 & 3.13 & 3.10 & 4.38 & 4.65 & 4.53 & 3.88 & 4.12 & 4.01 \\
\hline SEm \pm & 0.041 & 0.032 & 0.046 & 0.128 & 0.167 & 0.147 & 0.202 & 0.214 & 0.207 & 0.179 & 0.190 & 0.184 \\
\hline C.D $(P=0.05)$ & NS & NS & NS & 0.32 & 0.46 & 0.39 & 0.58 & 0.68 & 0.63 & 0.52 & 0.61 & 0.56 \\
\hline \multicolumn{13}{|c|}{ Systems of rice cultivation $(\mathbf{S})$} \\
\hline $\mathrm{S}_{1}: \mathrm{SRI}$ & 0.64 & 0.71 & 0.67 & 3.44 & 3.35 & 3.39 & 5.10 & 5.48 & 5.28 & 4.52 & 4.85 & 4.68 \\
\hline $\mathbf{S}_{2}: \mathbf{D S}$ & 0.42 & 0.49 & 0.46 & 3.11 & 3.13 & 3.12 & 4.57 & 5.05 & 4.75 & 4.05 & 4.47 & 4.21 \\
\hline $\mathrm{S}_{3}: \mathbf{N T P}$ & 0.48 & 0.62 & 0.55 & 2.93 & 2.89 & 2.91 & 4.31 & 4.64 & 4.47 & 3.82 & 4.11 & 3.96 \\
\hline SEm \pm & 0.032 & 0.041 & 0.038 & 0.112 & 0.131 & 0.126 & 0.212 & 0.218 & 0.223 & 0.188 & 0.193 & 0.198 \\
\hline C.D $(P=0.05)$ & NS & NS & NS & 0.38 & 0.34 & 0.36 & 0.65 & 0.70 & 0.67 & 0.58 & 0.62 & 0.60 \\
\hline \multicolumn{13}{|l|}{ Cultivars (C) } \\
\hline $\begin{array}{l}C_{1}: \text { DRR Dhan } \\
42\end{array}$ & 0.52 & 0.54 & 0.53 & 2.93 & 2.96 & 2.94 & 4.42 & 4.56 & 4.53 & 3.92 & 4.04 & 4.01 \\
\hline $\begin{array}{l}C_{2}: \text { DRR Dhan } \\
43\end{array}$ & 0.59 & 0.66 & 0.62 & 3.59 & 3.80 & 3.69 & 5.15 & 5.40 & 5.27 & 4.56 & 4.78 & 4.67 \\
\hline$C_{3}:$ MTU-1010 & 0.56 & 0.59 & 0.59 & 3.34 & 3.67 & 3.48 & 4.98 & 5.11 & 5.05 & 4.41 & 4.53 & 4.47 \\
\hline$C_{4}:$ NLR-34449 & 0.55 & 0.57 & 0.56 & 3.09 & 3.22 & 3.15 & 4.76 & 4.64 & 4.70 & 4.22 & 4.11 & 4.16 \\
\hline $\mathrm{SEm} \pm$ & 0.041 & 0.025 & 0.033 & 0.145 & 0.161 & 0.153 & 0.186 & 0.204 & 0.195 & 0.165 & 0.181 & 0.173 \\
\hline C.D $(P=0.05)$ & NS & NS & NS & 0.34 & 0.38 & 0.36 & 0.61 & 0.76 & 0.68 & 0.54 & 0.68 & 0.61 \\
\hline Interactions & NS & NS & NS & NS & NS & NS & NS & NS & NS & NS & NS & NS \\
\hline General Mean & 0.55 & 0.60 & 0.58 & 3.21 & 3.30 & 3.25 & 4.74 & 4.99 & 4.86 & 4.20 & 4.42 & 4.31 \\
\hline
\end{tabular}


Table.2 Crop growth rate $\left(\mathrm{g} \mathrm{m}^{-2}\right.$ day $\left.^{-1}\right)$ of rice cultivars as influenced by different irrigation regimes and establishment methods during Kharif 2017 and 2018

\begin{tabular}{|c|c|c|c|c|c|c|c|c|c|}
\hline \multirow[t]{3}{*}{ Treatments } & \multicolumn{9}{|c|}{ Crop growth rate $\left(\mathrm{g} \mathrm{m}^{-2}\right.$ day $\left.^{-1}\right)$} \\
\hline & \multicolumn{3}{|c|}{ 30-60 DAS/DAT } & \multicolumn{3}{|c|}{ 60-90 DAS/DAT } & \multicolumn{3}{|c|}{90 DAS/DAT-At harvest } \\
\hline & 2017 & 2018 & Pooled & 2017 & 2018 & Pooled & 2017 & 2018 & Pooled \\
\hline \multicolumn{10}{|c|}{ Irrigation regimes (I) } \\
\hline $\mathbf{I}_{1}: \mathbf{A W D}$ & 10.80 & 10.90 & 10.85 & 47.79 & 58.14 & 54.22 & 14.56 & 16.45 & 15.50 \\
\hline $\mathbf{I}_{2}:$ Saturation & 10.42 & 10.64 & 10.53 & 42.32 & 52.66 & 48.23 & 12.54 & 13.91 & 13.73 \\
\hline SEm \pm & 0.204 & 0.165 & 0.062 & 1.361 & 1.497 & 1.424 & 0.524 & 0.735 & 0.612 \\
\hline C.D $(P=0.05)$ & 0.36 & 0.24 & 0.30 & 3.96 & 3.44 & 3.70 & 1.51 & 2.11 & 1.77 \\
\hline \multicolumn{10}{|c|}{ Systems of rice cultivation $(\mathbf{S})$} \\
\hline$S_{1}:$ SRI & 15.50 & 16.05 & 15.77 & 49.64 & 57.43 & 53.54 & 15.37 & 18.33 & 16.85 \\
\hline $\mathrm{S}_{2}: \mathrm{DS}$ & 13.58 & 14.00 & 13.79 & 43.40 & 52.78 & 48.09 & 13.90 & 14.67 & 13.29 \\
\hline $\mathbf{S}_{3}: \mathbf{N T P}$ & 12.34 & 12.80 & 12.57 & 42.13 & 51.99 & 47.06 & 12.38 & 13.04 & 12.71 \\
\hline SEm \pm & 0.584 & 0.405 & 0.471 & 1.102 & 2.074 & 1.582 & 0.344 & 0.404 & 0.374 \\
\hline C.D $(P=0.05)$ & 1.88 & 1.30 & 1.54 & 3.58 & 4.02 & 3.80 & 1.12 & 0.14 & 0.13 \\
\hline \multicolumn{10}{|l|}{ Cultivars (C) } \\
\hline$C_{1}:$ DRR Dhan 42 & 9.96 & 9.24 & 9.60 & 44.11 & 50.81 & 47.46 & 13.44 & 15.22 & 14.33 \\
\hline$C_{2}:$ DRR Dhan 43 & 12.40 & 12.18 & 12.29 & 44.58 & 57.44 & 51.01 & 13.73 & 18.27 & 16.00 \\
\hline$C_{3}:$ MTU-1010 & 11.28 & 11.56 & 11.42 & 45.79 & 55.63 & 50.71 & 13.37 & 17.14 & 15.25 \\
\hline$C_{4}:$ NLR-34449 & 10.00 & 10.34 & 10.17 & 45.74 & 49.72 & 47.73 & 13.68 & 16.07 & 14.88 \\
\hline $\mathrm{SEm} \pm$ & 0.594 & 0.405 & 0.487 & 1.169 & 1.195 & 1.172 & 0.327 & 0.464 & 0.395 \\
\hline C.D $(P=0.05)$ & 1.67 & 1.14 & 1.35 & 3.39 & 3.46 & 3.42 & 0.94 & 1.14 & 1.10 \\
\hline Interactions & NS & NS & NS & NS & NS & NS & NS & NS & NS \\
\hline General Mean & 11.70 & 11.97 & 11.83 & 45.06 & 54.07 & 49.78 & 13.66 & 15.90 & 14.73 \\
\hline
\end{tabular}


Table.3 Relative growth rate $\left(\mathrm{g} \mathrm{g}^{-1}\right.$ day $\left.^{-1}\right)$ of rice cultivars as influenced by different irrigation regimes and establishment methods during Kharif 2017 and 2018

\begin{tabular}{|c|c|c|c|c|c|c|c|c|c|}
\hline \multirow[t]{3}{*}{ Treatments } & \multicolumn{9}{|c|}{ Relative growth rate $\left(\mathrm{g} \mathrm{g}^{-1}\right.$ day $\left.^{-1}\right)$} \\
\hline & \multicolumn{3}{|c|}{ 30-60 DAS/DAT } & \multicolumn{3}{|c|}{ 60-90 DAS/DAT } & \multicolumn{3}{|c|}{90 DAS/DAT-At harvest } \\
\hline & 2017 & 2018 & Pooled & 2017 & 2018 & Pooled & 2017 & 2018 & Pooled \\
\hline \multicolumn{10}{|c|}{ Irrigation regimes $(\mathrm{I})$} \\
\hline$I_{1}: A W D$ & 0.0417 & 0.0428 & 0.0423 & 0.0208 & 0.0214 & 0.0211 & 0.0026 & 0.0027 & 0.0026 \\
\hline $\mathbf{I}_{2}:$ Saturation & 0.0404 & 0.0417 & 0.0411 & 0.0202 & 0.0208 & 0.0205 & 0.0024 & 0.0026 & 0.0025 \\
\hline $\mathbf{S E m} \pm$ & 0.0024 & 0.0030 & 0.0027 & 0.0012 & 0.0015 & 0.0013 & 0.0001 & 0.0001 & 0.0001 \\
\hline C.D $(P=0.05)$ & NS & NS & NS & NS & NS & NS & NS & NS & NS \\
\hline \multicolumn{10}{|c|}{ Systems of rice cultivation (S) } \\
\hline $\mathbf{S}_{1}: \mathbf{S R I}$ & 0.0459 & 0.0477 & 0.0468 & 0.0229 & 0.0238 & 0.0234 & 0.0028 & 0.0029 & 0.0029 \\
\hline$S_{2}: D S$ & 0.0401 & 0.0427 & 0.0414 & 0.0200 & 0.0213 & 0.0207 & 0.0025 & 0.0026 & 0.0025 \\
\hline $\mathrm{S}_{3}:$ NTP & 0.0377 & 0.0390 & 0.0385 & 0.0188 & 0.0191 & 0.0192 & 0.0023 & 0.0024 & 0.0024 \\
\hline SEm \pm & 0.0029 & 0.0032 & 0.0030 & 0.0014 & 0.0016 & 0.0015 & 0.0001 & 0.0002 & 0.0001 \\
\hline C.D $(P=0.05)$ & NS & NS & NS & NS & NS & NS & NS & NS & NS \\
\hline \multicolumn{10}{|l|}{ Cultivars (C) } \\
\hline$C_{1}:$ DRR Dhan 42 & 0.0378 & 0.0408 & 0.0393 & 0.0189 & 0.0204 & 0.0196 & 0.0023 & 0.0025 & 0.0024 \\
\hline$C_{2}:$ DRR Dhan 43 & 0.0438 & 0.0459 & 0.0448 & 0.0219 & 0.0229 & 0.0224 & 0.0028 & 0.0030 & 0.0029 \\
\hline $\mathrm{C}_{3}: \mathrm{MTU}-1010$ & 0.0397 & 0.0419 & 0.0408 & 0.0198 & 0.0209 & 0.0204 & 0.0025 & 0.0028 & 0.0027 \\
\hline$C_{4}:$ NLR-34449 & 0.0408 & 0.0400 & 0.0404 & 0.0204 & 0.0200 & 0.0202 & 0.0024 & 0.0026 & 0.0025 \\
\hline SEm \pm & 0.0028 & 0.0021 & 0.0025 & 0.0014 & 0.0010 & 0.0012 & 0.0001 & 0.0001 & 0.0001 \\
\hline C.D $(P=0.05)$ & NS & NS & NS & NS & NS & NS & 0.0002 & 0.0003 & 0.0002 \\
\hline Interactions & NS & NS & NS & NS & NS & NS & NS & NS & NS \\
\hline General Mean & 0.0408 & 0.0425 & 0.0417 & 0.0204 & 0.0211 & 0.0208 & 0.0025 & 0.0026 & 0.0026 \\
\hline
\end{tabular}


Fig.1 Leaf area index of rice cultivars as influenced by different irrigation regimes and establishment methods (pooled means of Kharif 2017 and 2018)

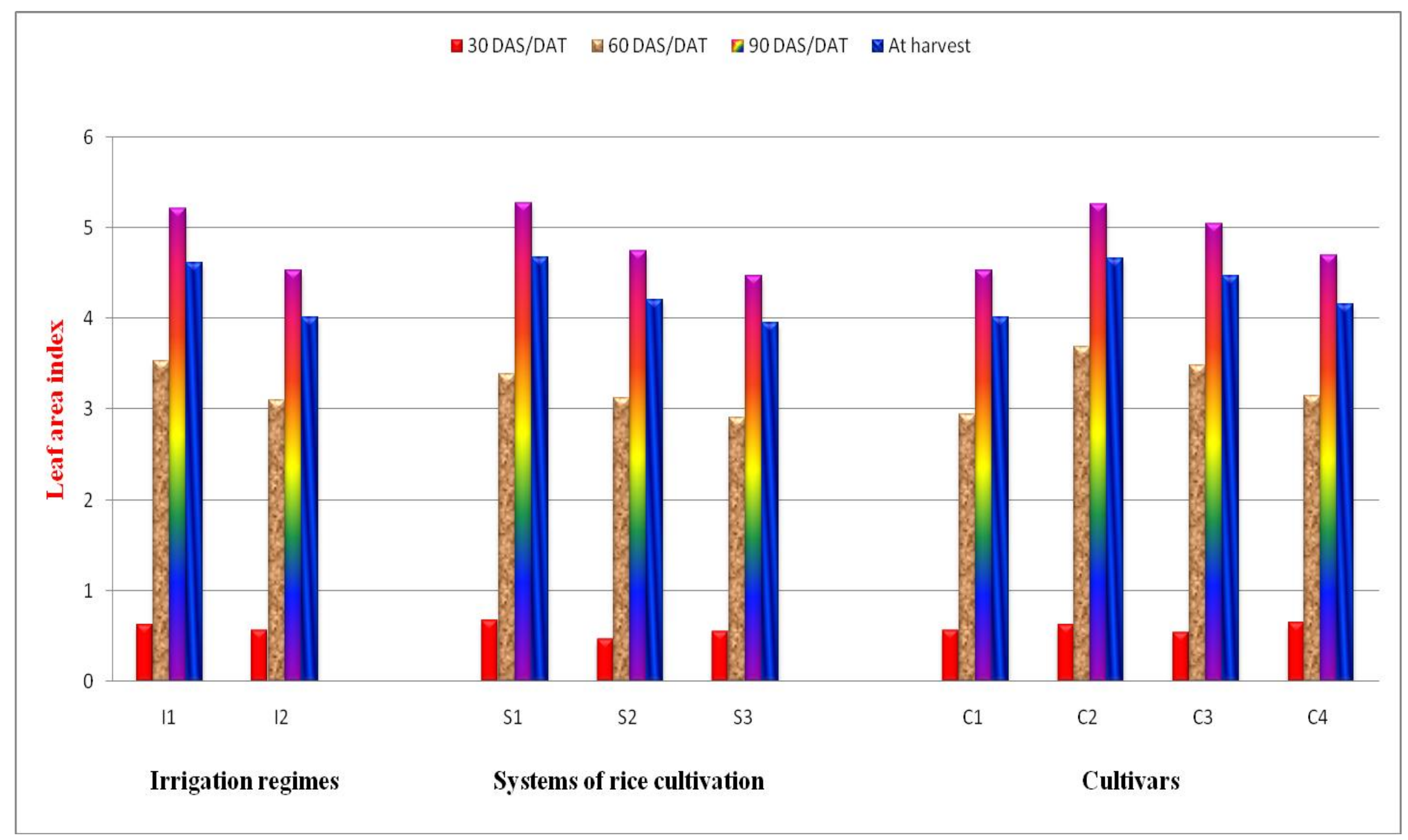


Fig.2 Crop growth rate $\left(\mathrm{g} \mathrm{m}^{-2} \mathrm{day}^{-1}\right)$ of rice cultivars as influenced by different irrigation regimes and establishment methods during Kharif 2017 and 2018
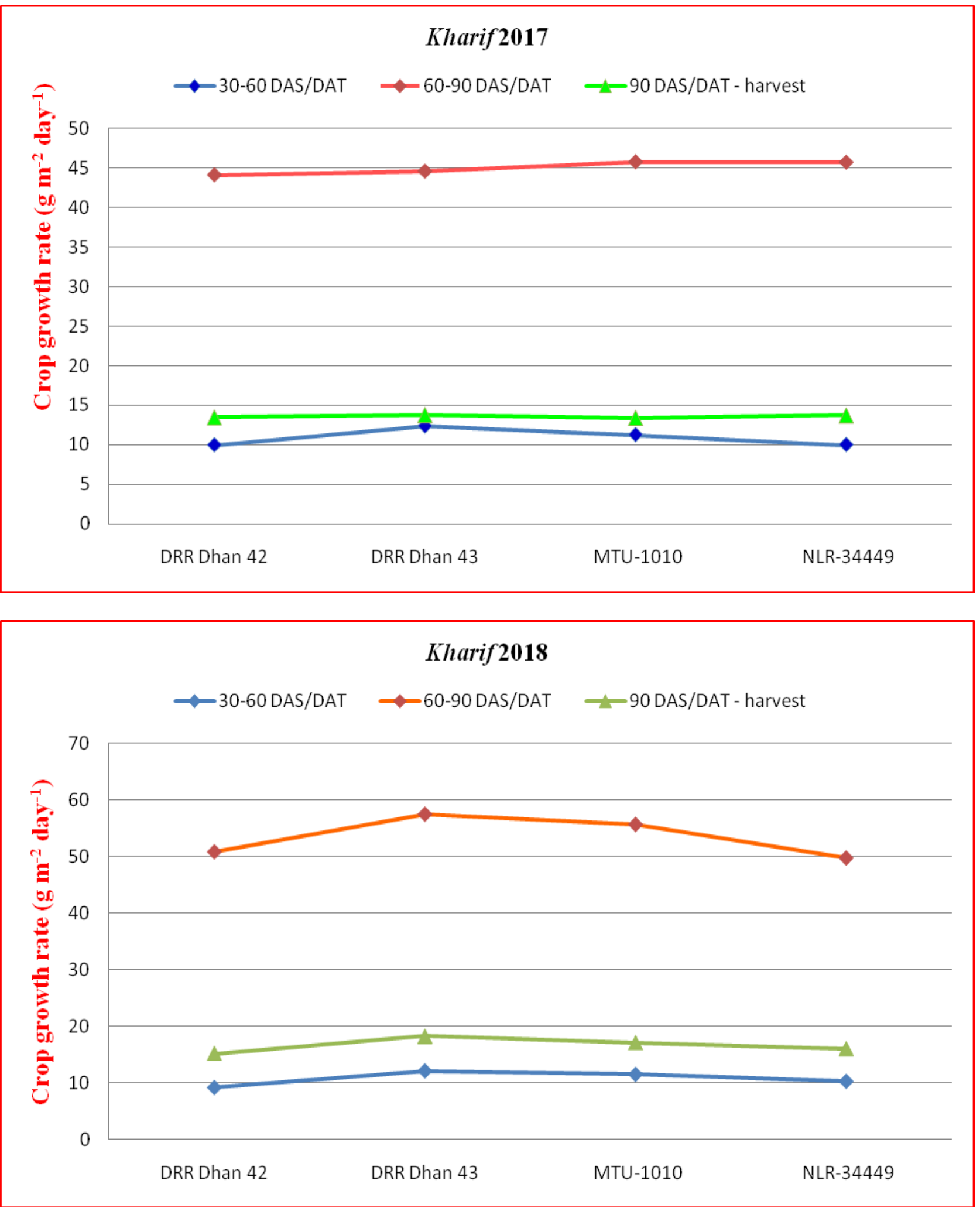
Fig.3 Relative growth rate $\left(\mathrm{g} \mathrm{g}^{-1}\right.$ day $\left.^{-1}\right)$ of rice cultivars as influenced by different irrigation regimes and establishment methods during Kharif 2017 and 2018
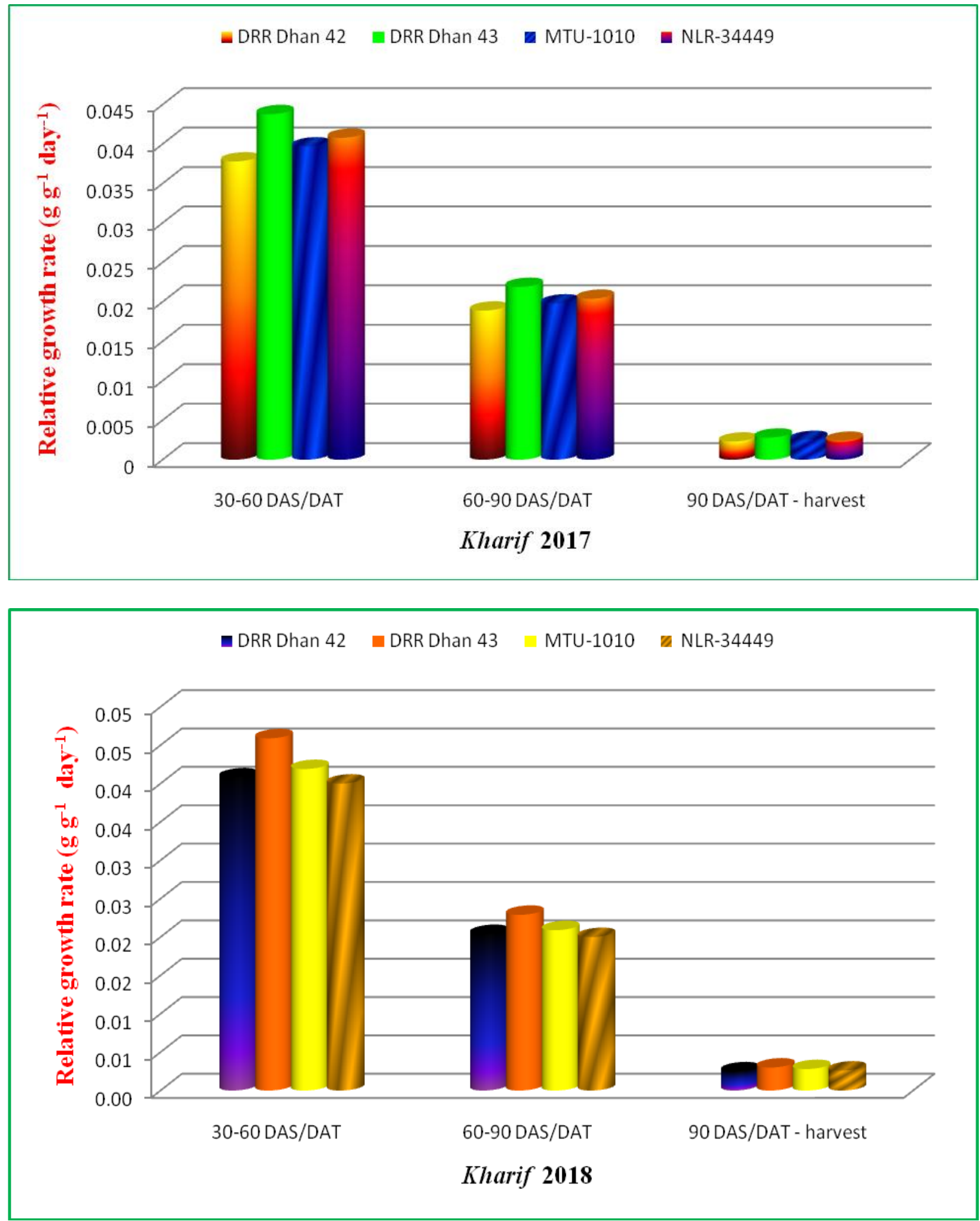


\section{Effect of systems of rice cultivation}

Among the systems of rice cultivation, system of rice intensification recorded significantly higher leaf area index as compared to normal transplanting and drum seeding during both the years at 30, 60, 90 DAS/DAT and harvest (Table 1 and Fig. 1). This might be due to planting in square geometry with wider spacing and single seedling which facilitated for better utilization of the resources to obtain maximum leaf area. These results are in conformity with Borkar et al., (2008), Pradeep (2009), Hussain et al., (2012) and Sridevi and Chellamuthu (2012). Among systems of rice cultivation at 30-60 DAS/DAT, 60-90 DAS/DAT and 90 DAS/DAT- harvest the CGR values recorded was significantly higher in system of rice intensification than normal transplanting and drum seeding during both the years of study (Table 2 and Fig. 2).

However the RGR was not significantly influenced by different systems of rice cultivation (Table 3 and Fig. 3). This was because of early vegetative growth due to planting of young seedlings raised in system of rice intensification and with better interception of solar radiation and greater net photosynthesis capacity might have contributed for higher crop growth rate. Biscoe and Gallagher (1978) reported that higher crop growth rate is usually upon rapid expansion of leaf area index to intercept available radiation in the growing season. Similar observations were also made by Pradeep (2009), Hussain et al., (2012) and Rajendran et al., (2013).

\section{Effect of rice Cultivars}

The cultivar DRR Dhan 43 recorded the highest leaf area index at 30, 60, 90 DAS/DAT and harvest during both the years of study as compared to other cultivars. The lowest LAI was produced by cultivar DRR Dhan 42 (Table 1 and Fig. 1). The results are in conformity with the findings of Ningaraju et al., (2015) and Vijay (2018).
Among all the cultivars DRR Dhan 43 recorded the significantly higher CGR values from 30-60 DAS/DAT, 60-90 DAS/DAT and 90 DAS/DAT- harvest as compared to other cultivars (Table 2 and Fig. 2). All the varieties recorded statistically similar values of RGR at all the growth stages except at 90 DAS/DATharvest.

Where in DDR Dhan 43 recorded the higher values of RGR, which was however an par with MTU-1010 (Table 3 and Fig. 3). The results are in conformity with the findings of Hussain et al., (2014), Ningaraju et al., (2015) and Vijay (2018).

\section{Effect of interaction}

The interaction effect of irrigation regimes, systems of rice cultivation and rice cultivars on LAI, CGR and RGR at all the growth stages in both the years and in pooled means was found to be statistically non-significant.

Results revealed that higher values of LAI and CGR were with DDR Dhan 43 grown under system of rice intensification method with alternate wetting and drying method irrigation on clay loam soils of Indian Institute of Rice Research (IIRR) during the kharif seasons of 2017 and 2018.

\section{References}

Biscoe, P.V and Gallagher, J.N. 1978. Physiological analysis of cereal yield. I. Production of dry matter. Agricultural Progress. 53: 34-50.

Borkar, L.S., Khawale, V.S., Raut, B., Patil, T.S and Kolte, H.S. 2008. Studies on spacing and nitrogen management under System of Rice Intensification (SRI). Journal of Soils and Crops. 18 (2): 438-411.

Hussain, A., Bhat, M.A and Ganie, M.A. 2012. Effect of number and age of seedlings on growth, yield, nutrient uptake and economics of rice (Oryza sativa) under system of rice intensification in temperate conditions. Indian Journal of Agronomy. 
57 (2): 133-137.

Hussain, S., Fujii, T., McGoey, S., Yamada, M., Ramzan, M and Akmal, M. 2014. Evaluation of different rice varieties for growth and yield characteristics. The Journal of Animal \& Plant Sciences. 24 (5): 1504-1510.

Kumar, S., Singh, R.S and Kumar, K. 2014. Yield and nutrient uptake of transplanted rice (Oryza sativa) with different moisture regimes and integrated nutrient supply. Current Advances in Agricultural Sciences. 6 (1): 64-66.

Ningaraju, G.K, Ramachandra, N., Shivakumar, M., Rajanna, $\mathrm{P}$ and Krishnamurthy, R. 2015. Studies on response of varieties and different dates of sowing on productivity of aerobic rice. Journal of Rice Research. 3(3): 24-29.

Pradeep, N. 2009. Studies on improvement of water productivity for rice (Oryza sativa L.) production through different methods of establishments. M. Sc. (Ag.) Thesis, University of Agricultural Sciences, Bangalore, India.

Rajendran, K., Raja, K.G and Balasubramanian, R. 2013. Evaluation of crop establishment techniques and weed management practices under system of rice intensification. Madras Agricultural Journal. 100 (7-9): 698-702.

Sandhu, S.S., Mahalb, S.S., Vashist, K.K., Buttar, G.S., Brar, A.S and Maninder, S. 2012. Crop and water productivity of bed transplanted rice as influenced by various levels of nitrogen and irrigation in north- west India. Agricultural Water Management. 104: 32-39.

Sonnentag, O., Talbot, J., Chen, J.M and Roulet, N.T. 2007. Using direct and indirect measurements of leaf area index to characterize the shrub canopy in an ombrotrophic peatland. Agricultural and Forest Meteorology. 144: 200-212.

Sridevi, V and Chellamuthu. V. 2012. Advantages of SRI cultivation in the tail end of Cauvery delta. Journal of Crop and Weed. 8 (2): 40-44.

Sudhakara, T.M. 2015. Evaluation of irrigation regimes and nitrogen management practices on production potential of rice [Oryza sativa (L.)] under mechanized SRI and SRI methods. Ph.D. Thesis, Professor Jayashankar Telangana State Agricultural University, Hyderabad.

Thakur, A.K., Rath, S., Patil, D.U and Kumar, A. 2011. Effects on rice plant morphology and physiology of water and associated management practices of the system of rice intensification and their implications for crop performance. Paddy Water Environment. 9: 13-24.

Vijay, K.P. 2018, Different duration rice (Oryza sativa L.) varieties as influenced by varied levels of nutrients application under irrigated ecology. M.Sc. (Ag.) Thesis. Indira Gandhi Krishi Vishwavidyalaya, Raipur, Chhattisgarh.

Yoshida, S. 1981. Fundamentals of Rice Crop Science. IRRI, Los Banos, Philippines: 269.

\section{How to cite this article:}

Venkataravana Nayaka, G. V., G. Prabhakara Reddy, R. Mahendra Kumar, P. Sudhakar and Surekha, G. 2019. Influence of Different Irrigation Regimes and Systems of Cultivation on Physiological Growth Parameters of Rice Cultivars.

Int.J.Curr.Microbiol.App.Sci. 8(07): 1068-1078. doi: https://doi.org/10.20546/ijcmas.2019.807.128 